\title{
Dinamika Multikultural Masyarakat Kota Surabaya
}

\author{
Soedarso, Muchammad Nurif, Sutikno dan Windiani
}

\begin{abstract}
ABSTRAK
Penelitian ini berujuan untuk menjelaskan kondisi dan faktor-faktor penyangga dari suatu masyarakat multikultur khususnya di Kota Surabaya.Metode penelitian yang digunakan adalah metode kualitatif yakni melalui studi literatur, penyebaran kuesioner dan interview mendalam.Penelitian ini menggunakan sample 5 lokasi kampung di Surabaya yang mewakili seluruh wilayah baik pusat, selatan, timur,utara dan barat yakni kampung Plampitan, Ketintang, Medokan Ayu, Kenjeran dan Manukan Lor. Kesimpulan hasil penelitian ini antara lain bahwa kondisi kampung-kampung di Surabaya selama ini telah hidup secara multikultural; antar warga tidak lagi membedakan secara diskriminatif persoalan etnis, agama dan tingkat kesejahteraan sosial di antara sesama warganya, dapat hidup rukun dan berdampingan satu sama lain. Kondisiini disebabkan antara lain karena faktor sejarah yang panjang serta kesediaan menerima perbedaan sebagai sebuah keniscayaan kehidupan kemasyarakatan.Pemerintah kota Surabaya juga mengembangkan sarana dan prasarana yang mendukung berbagai kegiatan kebersamaan di lingkungan warga seperti adanya taman-taman kota, pusat kuliner, kegiatan senam pagi lansia, organisasi kepemudaan Sinoman. Modal kultural dan sosial baik yang tumbuh dari masyarakat maupun yang diupayakan melalui usahausaha pemerintah merupakan faktor penting yang memungkinkan tetap bertahan dan semakin berkembangnya multikulturalisme warga masyarakat Kota Surabaya.
\end{abstract}

Kata Kunci: Multikultur, sejarah, menerima perbedaan, peran pemerintah, Kota Surabaya

Berdasarkan teori Cultural Pluralism: Mosaic Analogy, sebuah teori yang dikembangkan oleh Berkson ini berpandangan bahwa masyarakat yang terdiri dari individu-individu yang beragam latar belakang agama, etnik, bahasa, dan budaya, memiliki hak untuk mengekspresikan identitas budayanya secara demokratis (Garcia dalam Suparlan, 2002). Teori ini sama sekali tidak meminggirkan identitas budaya tertentu, termasuk identitas budaya kelompok minoritas sekalipun. Apabila dalam suatu masyarakat terdapat individu pemeluk agama Islam, Katholik, Protestan, Hindu, Budha, dan Konghucu, maka semua pemeluk agama diberi peluang untuk mengekspresikan identitas keagamaannya masing-masing. Apabila individu dalam suatu masyarakat berlatar belakang budaya Jawa, Madura, Betawi, dan Ambon, misalnya, maka masing-masing individu berhak menunjukkan identitas budayanya, bahkan diizinkan untuk mengembangkannya.

Masyarakat yang menganut teori ini, terdiri dari individu yang sangat pluralistik, sehingga masing-masing identitas individu dan kelompok dapat hidup jsh Jurnal Sosial Humaniora, Vol 6 No.1, Juni 2013 
dan menjalani kehidupan bermasyarakat dengan rukun dan damai. Gambaran teori Cultural Pluralism: Mosaic Analogy ini dipilih sebagai dasar pengembangan multikultural. Pada masyarakat Indonesia, teori ini sejalan dengan semboyan negara Indonesia, Bhinneka Tunggal Ika. Semboyan tersebut memberi peluang kepada semua bangsa Indonesia untuk mengekspresikan identitas bahasa, etnik, budaya, dan agama masing-masing, dan bahkan diizinkan untuk mengembangkannya.

Makalah ini bersumber dari sebagian dari hasil penelitian Hibah Penelitian Laboratorium LPPM ITS 2013 yang menggunakan dana BOPTN 2013. Metode penelitian yang digunakan adalah metode kualitatif dengan pendekatan penelitian tindakan (action research). Penelitian tersebut merupakan bagian dari roadmap penelitian suatu kelompok riset yang dalam hal ini adalah Kelompok Riset Rekayasa Sosial dan Kebijakan UPM Soshum ITS. Kelompok riset yang dibentuk dalam rangka menunjang penguatan keilmuan serta praktik-praktik di bidang sosial kemasyarakatan dan kebijakan publik.

\section{Perkembangan Masyarakat Surabaya}

Surabaya terletak di tepi pantai utara provinsi Jawa Timur. Wilayahnya berbatasan dengan Selat Madura di Utara dan Timur, Kabupaten Sidoarjo di Selatan, serta Kabupaten Gresik di Barat. Surabaya berada pada dataran rendah, ketinggian antara 3 - $6 \mathrm{~m}$ di atas permukaan laut kecuali di bagian Selatan terdapat 2 bukit landai yaitu di daerah Lidah dan Gayungan ketinggiannya antara 25 - $50 \mathrm{~m}$ di atas permukaan laut dan di bagian barat sedikit bergelombang. Surabaya terdapat muara Kali Mas, yakni satu dari dua pecahan Sungai Brantas. Gambaran wilayah Surabaya adalah sebagaimana dalam peta berikut ini: 


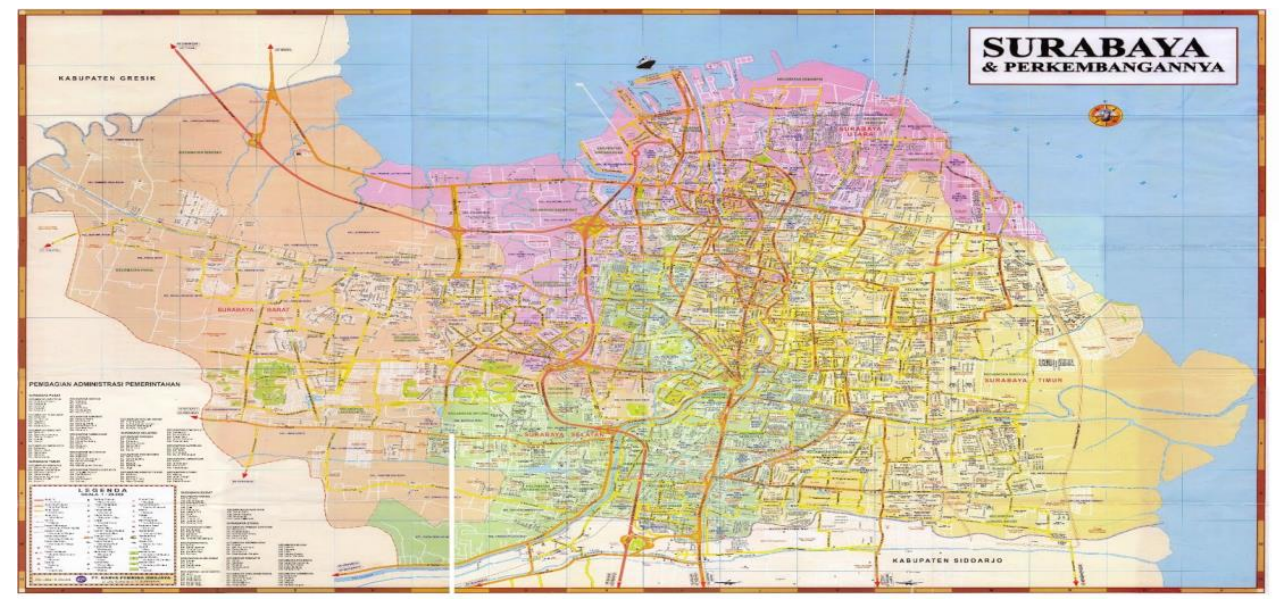

Sumber: http://desnantara-tamasya.blogspot.com/2011/03/peta-kota- surabaya.html

Surabaya dulunya merupakan gerbang Kerajaan Majapahit, yakni di muara Kali Mas. Hari jadi Kota Surabaya ditetapkan tanggal 31 Mei 1293 yakni berdasarkan penetapan oleh Walikotamdya Kepala Daerah Tingkat II Surabaya, yang dijabat oleh Bapak Soeparno, mengeluarkan Surat Keputusan No. 64/WK/75 tentang penetapan hari jadi kota Surabaya. Tanggal tersebut ditetapkan atas kesepakatan sekelompok sejarahwan yang dibentuk oleh Pemerintah Kota bahwa nama Surabaya berasal dari kata "Sura ing Bhaya" yang berarti “ Keberanian menghadapi bahaya “ diambil dari babak dikalahkannya pasukan Mongol utusan Kubilai Khan oleh pasukan Jawa pimpinan Raden Wijaya pada tanggal 31 Mei 1293. Pasukan Mongol yang datang dari laut digambarkan sebagai ikan SURO (ikan hiu/berani) dan pasukan Raden Wijaya yang datang dari darat digambarkan sebagai BOYO (buaya/bahaya), jadi secara harfiah diartikan berani menghadapi bahaya yang datang mengancam. Maka hari kemenangan itu diperingati sebagai hari jadi Surabaya.

Dari sisi penyebaran agama, agama Islam sudah mulai tersebar sejak abad ke-15, bahkan Islam menyebar dengan pesat di daerah Surabaya. Salah satu anggota Wali Songo, Sunan Ampel, mendirikan masjid dan pesantren di daerah Ampel. Tahun 1530, Surabaya menjadi bagian dari Kerajaan Demak. Menyusul runtuhnya Demak, Surabaya menjadi sasaran penaklukan Kesultanan Mataram, diserbu Panembahan Senopati tahun 1598, diserang besar-besaran oleh Panembahan Seda ing Krapyak tahun 1610, diserang Sultan Agung tahun 1614. Pemblokan aliran 
sungai Brantas oleh Sultan Agung akhirnya memaksa Surabaya menyerah. Suatu tulisan VOC tahun 1620 menggambarkan Surabaya sebagai negara yang kaya dan berkuasa. Panjang lingkarannya sekitar 5 mijlen Belanda (sekitar 37 km), dikelilingi kanal dan diperkuat meriam. Tahun tersebut, untuk melawan Mataram, tentaranya sebesar 30000 prajurit. Tahun 1675, Trunojoyo dari Madura merebut Surabaya, namun akhirnya didepak VOC pada tahun 1677. Dalam perjanjian antara Paku Buwono II dan VOC pada tanggal 11 November 1743, Surabaya diserahkan penguasaannya kepada VOC. Surabaya resmi berada di bawah kedaulatan kolonial Belanda. Pemerintahan pun berada di tangan Belanda. Di zaman kolonial tersebut, Belanda membagi-bagi masyarakat dalam kampung-kampung berdasarkan etnis, sehingga terdapat Kampung Pecinan, Kampung Arab, Kampung Bumiputra (inlander atau orang-orang Jawa/Melayu), dan Kampung Eropa (Renjanatuju, 2013).

Kampung-kampung etnis ini muncul karena peraturan Wijkenstensel yang berisi setiap etnis harus menempati kampung etnisnya masing-masing. Peraturan Passenstensel juga menyatakan bahwa seseorang harus menunjukkan surat jalan jika hendak keluar dari lingkungan. Kedua peraturan ini menyebabkan akses keluarmasuk di kawasan Kampung Arab, Pecinan, atau pribumi menjadi sulit. Pembagian kampung berdasarkan etnis ini terjadi bukan karena etnis-etnis tersebut mengeksklusifkan diri atau tidak mau berbaur. Namun, ini adalah upaya Belanda untuk mengontrol populasi dan kriminalitas di Surabaya dan cara Belanda melakukan pengawasan, misalnya jika ada kerusuhan atau pemberontakan, maka intel Belanda mudah mencari tersangka. Intel Belanda tinggal mencari ciri-ciri pelakunya berdasarkan identitas etnis misalnya pakaian yang dipakai apakah gamis, cheong-sam, atau sarung, dan sebagainya.

Seiring waktu, kampung-kampung ini mengalami perkembangan, baik itu positif ataupun negatif. Ada kampung etnis yang mengalami perluasan, tetapi ada pula yang hanya meninggalkan bangunan fisiknya sementara manusianya tidak tersisa. Kampung Pecinan, misalnya, adalah kampung yang mengalami perkembangan. Pada awalnya, Kampung Pecinan terbentuk di Chinesche Voorstraat atau Pecinan Kulon (kini Jalan Karet) yang menghadap Sungai Kalimas. Konon, posisi ini dapat membawa keberuntungan. Di masa-masa awal, Kampung Pecinan 
juga muncul di Jalan Tepekong (kini Jalan Coklat). Sebagai penanda, ada klenteng tertua di Surabaya bernama Hok An Kiong (klenteng Dewa Mazu) yang berada di kawasan Jalan Coklat. Kini, kampung orang-orang Tionghoa ini berada di kawasan Kembang Jepun, dengan dibatasi kawasan Ampel di utara; Pasar Atum, Stasiun Semut, dan Jagalan di selatan; Simokerto, Kali Pegirikan, dan Kapasan di Timur; serta Kalimas dan Jalan Rajawali di barat (ibid., 2013).

Jalan Kembang Jepun merupakan simbol bahwa orang Tionghoa berperan penting dalam membangun perekonomian kota. Kawasan ini bahkan menjadi penghubung antara kawasan perdagangan Eropa (Heerenstraat) dan kawasan lain yang berkembang di selatan Surabaya. Penanda Kembang Jepun adalah sebuah gapura tinggi besar dengan ornamen dua naga di atas gapura yang sudah ada di situ sejak 2003. Naga itu berhadap-hadapan; kanan dan kiri. Tulisan Kya Kya tertulis di gapura itu. PT Kya Kya bekerja sama dengan Pemkot Surabaya sempat berupaya mengembalikan lagi kejayaan Kembang Jepun di masa lalu.

Kampung etnis lain adalah Ampel atau Kampung Arab. Hingga kini masih ramai dan masih banyak dihuni oleh orang Arab. Kampung Arab ini telah ada sejak zaman Majapahit. Raja kala itu, Bhre Kertabumi, memberikan sebidang lahan di Ampel Denta kepada Sayyid Ali Rahmatullah sebagai rasa terima kasih atas bantuan Sayyid Ali mengatasi kemorosotan di Majapahit.

Ampel Denta kemudian berkembang sebagai pusat ilmu agama Islam. Di luar itu, kawasan ini juga menjadi kawasan perdagangan yang diramaikan oleh (sebagian besar) pendatang dari Arab. Pasar Ampel merupakan pasar tertua di Surabaya dengan pusat jual beli yang sudah terjadi sejak tahun 1420. Kini, Kampung Arab berkembang dengan batasan di sebelah utara adalah Jalan Danakarya, selatan Pasar Pabean, timur kali Pegirian, dan barat adalah Sungai Kalimas. Terbentuk menjadi kampung yang islami, dari segi bangunan, Kampung Arab dihiasi oleh bangunan-bangunan lama berarsitektur Melayu, seperti rumah kampung, pasar, masjid, dan lain-lain.

Kondisi yang berbeda dialami pada Kampung Eropa. Kampung ini sudah tidak lengkap lagi dengan warga keturunan Eropa di dalamnya. Yang tersisa hanyalah bangunan-bangunan tua bergaya Eropa di beberapa titik di Surabaya, 
seperti Darmo. Pada 1870-an, di Jalan Rajawali dan Jalan Veteran didirikan banyak perkantoran dan pertokoan berarsitektur Belanda. Pada 1890-an, arsitektur Eropa ada di selatan Surabaya, yaitu sepanjang Ketabang hingga Darmo. Ketika perdagangan di Kampung Eropa tumbuh subur pada 1900-an, kawasan ini meluas hingga ke Gemblongan, Tunjungan, dan Kaliasin.

Orang-orang Eropa sudah tidak tersisa lagi sejak masa nasionalisasi atau pascakemerdekaan 1945. Saat itu, semua orang bersiap akan kedatangan bangsa Belanda yang akan kembali menjajah Indonesia. Sementara, orang-orang Belanda yang memang masih ada di Indonesia boleh tinggal di kawasan perumahan mereka (di Darmo), dengan syarat tidak boleh ke mana-mana. Pada masa itu, para pejuang mengambil secara sepihak rumah-rumah orang Belanda. Karena sudah kalah, orangorang Belanda itu ingin mengklaim kembali rumah-rumah mereka, tapi sulit. Opsinya hanya dua: tinggal di Indonesia dan menjadi warga negara Indonesia, atau pulang ke Belanda. Mereka seperti dipaksa untuk pulang ke negaranya sendiri, dan kenyataannya, banyak yang lebih memilih untuk mudik ke Belanda. Sehingga fisik bangunan masih ada, tetapi penghuninya tidak ada lagi. Menurut Dukut Imam Widodo, penulis Hikajat Soerabaya Tempo Doeloe, hilangnya bangsa Eropa di Surabaya tidak semata-mata hanya karena mereka pulang ke negara asalnya:

"Dulu, ada bunker di Balai Pemuda. Saat itu, Balai Pemuda masih bernama Simpangsche Societeit. Ketika masa nasionalisasi, orang-orang Belanda yang ditahan di kamp interniran dibebaskan. Oleh para pemuda Indonesia, orang-orang Belanda digiring ke Balai Pemuda. Semua dibunuh dan mayatnya disimpan di bunker itu," cerita Dukut.

Kampung Eropa kini hanya tersisa bangunan-bangunannya saja. Kampungkampung etnis yang sampai kini masih ada dalam peta dinamika Kota Surabaya adalah Kampung Pecinan, Kampung Arab, Kampung Bumiputra atau pribumi. Berdasarkan rencana tata ruang wilayah Surabaya tahun 2012 yang disusun Pemerintah Kota (Pemkot) Surabaya, maka kawasan permukiman menjadi wilayah yang paling luas dibandingkan kawasan perkantoran, industri, atau perdagangan. Sekitar 70\% kebutuhan untuk permukiman pada tahun 1988 berasal dari kampungkampung (Renjanatuju, 2013). 


\section{Kondisi Multikultural Masyarakat Kota Surabaya}

Menurut Sensus Penduduk Tahun 2010, Kota Surabaya memiliki jumlah penduduk sebanyak 2.765.908 jiwa. Dengan wilayah seluas $333,063 \mathrm{~km}^{2}$, maka kepadatan penduduk Kota Surabaya adalah sebesar 8.304 jiwa per $\mathrm{km}^{2}$. Data terakhir yang disampaikan Dinas Kependudukan Kota Surabaya melalui website-nya (http://dispendukcapil.surabaya.go.id /index.php: diunduh pada tanggal 27 Agustus 2013) tercatat bahwa penduduk Surabaya telah mencapai sebanyak 3.176.771 jiwa.

Suku Jawa adalah suku mayoritas di Surabaya. Dibanding dengan masyarakat Jawa pada umumnya, Suku Jawa di Surabaya memiliki temperamen yang lebih keras dan egaliter. Salah satu penyebabnya adalah jauhnya Surabaya dari kraton yang dipandang sebagai pusat budaya Jawa. Meskipun Jawa adalah suku mayoritas $(83,68 \%)$, tetapi Surabaya juga menjadi tempat tinggal berbagai suku bangsa di Indonesia, termasuk suku Madura (7,5\%), Tionghoa (7,25\%), Arab (2,04\%), dan sisanya merupakan suku bangsa lain seperti Bali, Batak, Bugis, Manado, Minangkabau, Dayak, Toraja, Ambon, dan Aceh atau warga asing.

Sebagai pusat pendidikan, Surabaya juga menjadi tempat tinggal mahasiswa dari berbagai daerah dari seluruh Indonesia, bahkan di antara mereka juga membentuk wadah komunitas tersendiri. Sebagai pusat komersial regional, banyak warga asing (ekspatriat) yang tinggal di daerah Surabaya, terutama di daerah Surabaya Barat.

Dalam website resmi pemerintah Kota Surabaya (www.surabaya.go.id) juga dijelaskan bahwa agama Islam adalah agama mayoritas penduduk Surabaya. Surabaya merupakan salah satu pusat penyebaran agama Islam yang paling awal di tanah Jawa dan merupakan basis warga Nahdatul Ulama yang beraliran moderat. Masjid Ampel didirikan pada abad ke-15 oleh Sunan Ampel, salah satu pioner Walisongo. Agama lain yang dianut sebagian warga adalah Kristen Protestan, Katolik, Hindu, Buddha, dan Konghucu. Walaupun Islam merupakan mayoritas di Surabaya kerukunan umat beragama saling menghormati, menghargai dan saling menolong untuk sesamanya cukuplah besar, niat masyarakat Surabaya dalam 
menjalankan ibadahnya, hal ini bisa dilihat bangunan Masjid Agung Surabaya bersebelahan dengan salah satu gereja besar di kota ini.

Di kota Surabaya juga berdiri Gereja Bethany yang merupakan gereja terbesar di Asia Tenggara. Tidak hanya itu saja banyaknya yayasan-yayasan sosial yang berazaskan agama juga banyak, mereka bekerja sama dalam kegiatan bakti sosial. Bahkan ada satu wadah Kerukunan Umat Beragama di Surabaya yang sering menyikapi suatu problem sosial manusia agar tidak mudah terprovokasi oleh pihakpihak yang tidak bertanggung jawab yang akan merusak persatuan dan kesatuan Bangsa Indonesia pada umumnya serta masyarakat Jawa Timur khususnya. Agama lainnya adalah Yahudi \& bahkan terdapat sebuah synagoga (tempat ibadah Yahudi) di jalan Kaayon, dekat stasiun gubeng. Umumnya mereka adalah imigran Yahudi dari Baghdad \& Yahudi asal Belanda. Ini semakin di perjelas dengan adanya makam khusus orang Yahudi di daerah Kembang Kuning, Surabaya.

Surabaya memiliki dialek khas Bahasa Jawa yang dikenal dengan Boso Suroboyoan. Dialek ini dituturkan di daerah Surabaya dan sekitarnya, dan memiliki pengaruh di bagian timur Provinsi Jawa Timur. Dialek ini dikenal egaliter, blakblakan, dan tidak mengenal ragam tingkatan bahasa seperti Bahasa Jawa standar pada umumnya. Masyarakat Surabaya dikenal fanatik dan bangga terhadap bahasanya, akan tetapi oleh karena perkembangan budaya dan banyaknya pendatang yang datang ke Surabaya yang telah mencampuradukkan bahasa Suroboyo, Jawa Ngoko dan Madura, maka bahasa asli Suroboyo sebagian perlahan mulai punah, misal kata-kata: Njegog (Belok), Ndherok (Berhenti), Gog(Paman), Maklik (Tante).

\section{Mengokohkan Integrasi Masyarakat}

Dalam kaitan dengan penelitian kampung multikultural di Kota Surabaya ini, juga telah diperoleh data-data yang menunjukkan terjalinnya integrasi dalam masyarakat. Dalam pengertian, seiring perkembangan masyarakat, dan juga sifat multikulturalnya, maka integrasi yang terjadi pada masyarakat Kota Surabaya adalah bentuk integrasi rasional (gesselschaft) artinya integrasi hanya akan terjadi manakala menguntungkan masing-masing pihak, tidak merugikan antar pihak. Dengan demikian maka dalam integrasi semacam itu dituntut setiap pihak yang terlibat 
untuk selalu menjaga norma-norma bersama, karena jiga terjadi pelanggaran terhadap norma bersama sama halnya akan memicu diisntegrasi.

Berdasarkan kompilasi hasil kuesioner dalam penelitian ini menunjukkan bahwa mayoritas responden sangat setuju untuk mengembangkan perikehidupan bersama yang bersifat multikultural. Perbedaan-perbedaan yang ada, baik menyangkut ras (etnis, kesukuan), keagamaan, kemampuan sosial dan ekonomi, politik, dan sebagainya antar komponen warga masyarakat bukanlah halangan untuk menjalin hidup rukun dan bekerjasama antar sesama masyarakat. Para warga memiliki prinsip bahwa, satu sama lain tidak boleh saling mengganggu kepentingannya masing-masing.

Pengertian integrasi nasional menurut Syamsuddin (1994) sebenarnya mencakup pula bagaimana meningkatkan konsensus normatif yang mengatur prilaku setiap anggota masyarakat, konsensus ini tumbuh dan berkembang diatas nilai-nilai dasar yang dimiliki bangsa secara keseluruhan. Sosiolog Duverger (Suparlan, 2002) mengatakan bahwa Integrasi dibangun dari interdependensi yang lebih rapat antara bagian-bagian antara organisme hidup atau antar anggota-anggota dalam masyarakat, sehingga integrasi adalah proses mempersatukan masyarakat,yang cenderung membuatnya menjadi suatu kata yang harmonis yang didasarkan pada tatanan yang oleh angota-anggotanya dianggap sama harmonisnya. Berdasarkan dua pengertian integrasi sosial tersebut maka integrasi diwujudkan dengan upaya menyatukan semua unsur masyarakat yang majemuk yang dibangun dari nilai-nilai kultur yang ada dalam masyarakat majemuk tadi, sehingga terjadi kesepakatan bersama dalam mencapai tujuan untuk kepentingan bersama.

Masyarakat kota Surabaya juga sangat menghendaki peran aktif pemerintah dan tokoh masyarakat dalam ikut menjaga dan mengembangkan kerukunan hidup bersama, dan juga dalam ikut mengatasi konflik-konflik yang timbul dalam hubungan sosial kemasyarakatan. Kasus-kasus yang terpapar dalam kuesioner, meskipun belum sepenuhnya tuntas dalam hal penyelesaiannya, namun setidaknya sejauh ini tidak pernah sampai berpotensi menjadi konflik sosial yang membesar. Hal ini tentu karena peran serta aktif pemerintah dan tokoh masyarakat. Hal ini 
sekaligus pula menjawab persoalan mengapa di Kota Surabaya mampu menjaga konduktifitas masyarakatnya.

Fasilitas-fasilitas yang disediakan pemerintah kota juga sangat membantu tersedianya sebuah ruang publik yang mampu mendorong interaksi positip antar warga masyarakat. Sarana-sarana yang terbatas mampu ditutup dengan inovasiinovasi kegiatan sosial elemen masyarakat, misalnya melalui senam bersama, perayaan keagamaan, kerja bakti lingkungan yang melibatkan seluruh warga. Berikut ini contoh kegiatan senam bersama yang dilakukan secara rutin setiap minggu pagi di kampung Ketintang:

Integrasi merupakan perpaduan seluruh unsur dalam rangka melaksanakan kehidupan bersama, meliputi sosial, budaya, ekononi, maka pengertian integrasi nasional adalah menekankan pada persatuan persepsi dan perilaku diantara kelompok-kelompok dalam masyarakat. Integrasi masyarakat dapat tercapai apabila: pertama, terciptanya kesepakatan dari sebagian besar anggotanya terhadap nilai-nilai sosial tertentu yang bersifat fundamental dan krusial; kedua, sebagian besar anggotanya terhimpun dalam berbagai unit sosial yang saling mengawasi dalam aspek-aspek sosial yang potensial; ketiga, terjadinya saling ketergantungan diantara kelompok-kelompok social yang terhimpun di dalam pemenuhan kebutuhan bersama. Melalui proses integrasi ini akan mampu membangun suatu harmoni sosial dalam masyarakat (Syamsuddin, 1994).

\section{Pembangunan Karakter Masyarakat yang Berkelanjutan}

Berbagai pendekatan pembangunan telah lama diterapkan di Kota Surabaya. Jaman Belanda pembangunan perkotaan dilakukan dengan membagi wilayah-wilayah hunian berdasarkan unsur etnisitas: Eropa, Arab,Cina,dan Pribumi; bahkan dengan menerapkan ijin untuk masuk atau keluar untuk tiap-tiap wilayah. Pada pola pembagian masyarakat semacam ini jelas bahwa komunikasi dan potensi percampuran etnis sangat terbatas.

Berpijak pada naskah akademik Pendidikan Karakter di Perguruan Tinggi yang dikeluarkan Kementerian Pendidikan dan Kebudayaan (2013) maka arah pembangunan karakter adalah terbentuknya suatu masyarakat yang tangguh, 
berakhlak mulia dan bermoral berlandaskan falsafah Pancasila. Watak dan perilaku yang dikehendaki antara lain: bertaqwa kepada Tuhan YME, berbudiluhur, tolerans, berjiwa patriotik, dan seterusnya. Nilai-nilai Pancasila menjadi hal penting indikator sebuah karakter masyarakat karena sekaligus sebagai cermin menguatnya jati diri, kepribadian dan peradaban bangsa.

Demikian halnya sebagaimana terpapar dari hasil interview di atas bahwa masyarakat Surabaya telah sepenuhnya menerima multikulturalisme sebagai sebuah kenyataan, bahkan telah memiliki sejarah panjang di Surabaya sebagai sebuah kota dagang dan pelabuhan. Penerimaan akan multikulturalisme ini ditunjukkan dengan terjadinya konflik yang berlatar belakang etnis atau keagamaaan atau pun karena kesenjangan sosial, sebagaimana kadang terjadi di kota lain seperti Jakarta. Konflikkonflik dan atau problem kemasyarakatan selama ini terjadi karena faktor sengketa administrasi dan atau salah paham antara kedua belah pihak.

Tokoh masyarakat dan organisasi kemasyarakat selama ini lebih banyak berperan positif, keberadaannya dibutuhkan oleh masyarakat sebagai perekat sosial dan sekaligus pihak yang dianggap mampu membantu penyelesaian seandainya timbul konflik antar masyarakat. Dari diskusi khusus yang dilakukan dengan tokoh masyarakat juga diketahui bahwa warga masyarakat kota Surabaya, khususnya pemuda-nya, memiliki sebuah wadah yang cukup efektif yang disebut sebagai 'Sinoman'. Sinoman telah ada sejak jaman perjuangan merebut kemerdekaan 1945, berperan dalam peristiwa bersejarah 10 Nopember 1945 yakni melakukan penyobekan bendera Belanda sehingga menjadi Merah Putih, dan hingga sekarang organisasi Sinoman ini tetap ada dan memiliki peran penting membantu beberapa kebutuhan masyarakat misal: membantu hajatan, bencana, dan lain-lain yang memerlukan uluran tangan para genarasi muda.

Sinergi antara tokoh masyarakat, pemuda dan warga secara keseluruhan merupakan karakter khas masyarakat Surabaya. Sinergi ini memungkinkan masyarakat memiliki sistem untuk menangkal atau mengurangi potensi bahaya, dan serta menjadi modal sosial yang efektif untuk terus mengembangkan kehidupan kemasyarakatan dalam suasana multikultural. 


\section{Kesimpulan}

Kondisi kampung Surabaya selama ini hidup secara multikultural; antar warga tidak membedakan secara diskriminatif persoalan etnis, agama dan tingkat kesejahteraan sosial di antara sesama warganya, dapat hidup rukun dan berdampingan satu sama lain. Aspek yang menyebabkan kondisi ini antara lain karena faktor kesejarahan yang panjang serta kesediaan menerima multikulturalisme sebagai sebuah keniscayaan kehidupan kemasyarakatan. Kesedian menerima, saling percaya, berbagi dan hidup berdampingan merupakan modal kultural yang menguatkan kehidupan multikulturalisme.

Peran dan tindakan masyarakat dalam turut mengembangkan kehidupan multikultural adalah dengan pelibatan dan partisipasi semua elemen masyarakat khususnya para tokoh masyarakat yang bersifat formal seperti aparatur pemerintahan maupun non formal seperti tokoh yang dituakan, tokoh agama. Pemerintah kota Surabaya juga mengembangkan sarana dan prasaranan yang mendukung berbagai kegiatan kebersamaan di lingkungan warga seperti adanya taman-taman kota, pusat kuliner, kegiatan senam pagi lansia, organisasi kepemudaan Sinoman. Sistem sosial bentukan pemerintah dan berbagai kegaitan kemasyarakatan pada hakikatnya merupakan modal sosial yangpenting yang memungkinkan tetap bertahan dan semakin berkembangnya multikulturalisme warga masyarakat Kota Surabaya.

Pola kehidupan masyarakat Surabaya sebagai masyarakat kota dagang dan pelabuhan, dan seiring bertumbuh pesatnya dunia industri, menyebabkan semakin plural-nya corak kehidupan sebagai sebuah kenyataan yang tak terhindarkan. Di tingkat kampung-kampung di Kota Surabaya, peran tokoh masyarakat dan juga pemuda sangat penting kedudukannya dalam menciptakan integrasi masyarakat. Ke depan pola integrasi yang bertumpu pada tokoh masyarakat dan pemuda dapat terus dikembangkan untuk mencapai peningkatan kesejahteraan bersama. Fungsi-fungsi sosial kepemudaan dapat ditransformasikan ke fungsi-fungsi yang lebih ekonomis sehingga mampu membawa pada dukungan bagi lebih terciptanya kemakmuran, daya saing, dan integrasi masyarakat. 


\section{Saran}

Kompleksitas kehidupan masyarakat perkotaan semakin lama semakin berkembang dengan semakin terbukanya sistem sosial dan kenegaraan. Hubungan antar negara semakin lama semakin terbuka, begitu pula hubungan antar masyarakat satu dengan lainnya semakin berinteraksi dengan munculnya perjanjian perdagangan bebas ASEAN dan Globalisasi. Oleh karena itu fondasi kondisi multikultural yang telah terbangun selama ini dapat terus dipertahankan dan dikembangkan antara lain dengan cara menjadikannya sebagai norma publik yang bersifat resmi. Setiap warga pendatang yang datang ke Surabaya dari manapun, atau pun para remaja yang hendak menginjak dewasa perlu mendapat 'penyuluhan' tentang karakter masyarakat Surabaya yakni 'masyarakat multikultural' sebagai bagian prasyarat mengurus KTP (kartu tanda penduduk), sebagai tanda sebagai warga Kota Surabaya. 


\section{Daftar Pustaka}

Kementrian Pendidikan dan Kebudayaan RI, 2013, Pendidikan Karakter di Perguruan Tinggi, Jakarta.

Renjanatuju, 2013, Surabaya dan Kampung-kampung Etnis, http://renjanatuju.wordpress. com/ 2013/03/19

Salim, A. 2002. Perubahan Sosial : Sketsa Teori dan Refleksi Metodologi Kasus Indonesia. PT. Tiara Wacana. Yogyakarta.

Suparlan, P., 2002. Kesetaraan Warga dan Hak Budaya Komuniti dalam Masyarakat Majemuk Indonesia. Jurnal Antropologi Indonesia, no. 6. Jakarta.

Syamsuddin, N. 1994. Integrasi dan Ketehanan Nasional di Indonesia. Lemhanas. Jakarta. Jogjakarta.

Sunyoto Usman, 2004, Sosiologi: Sejarah, Teori dan Metodologi, Cired,

Tilaar, H.A.R. 2004. Multikulturalisme: Tantangan-tantangan Global Masa Depan dalam Transformasi Pendidikan Nasional. Grasindo. Jakarta. 